\title{
URINARY AND FECAL EXCRETION OF MERCURY IN MAN FOLLOWING ADMINISTRATION OF MERCURIAL DIURETICS 1
}

\author{
By J. GROSSMAN, R. E. WESTON, R. A. LEHMAN, J. P. HALPERIN,2 \\ T. D. ULLMANN, AND L. LEITER \\ (From the Medical Division, Montefiore Hospital and the Department of Therapeutics, New \\ York University-Bellevue Medical Center, New York City)
}

(Submitted for publication June 18, 1951 ; accepted August 13, 1951)

The widespread use of mercurial diuretics has stimulated greater interest in the metabolism of organic mercurials in man. Recently proposed regimens (1) involving frequent, even daily, administration of mercurials, have focused particular attention on the 24 hour excretion of these compounds in relation to the cumulative toxicity of any mercury which may be retained. Moreover, little is known of the mechanism for eliminating mercury in the urine and its relation to the process of diuresis. Therefore, the following aspects of mercury excretion in man were studied: 1 ) the 24 hour urinary and fecal excretions of mercury after repeated administration of mercurial diuretics; 2) the course of urinary mercury excretion before, during and after the period of maximal diuretic response; 3 ) the effects on the excretion of mercury, water and electrolytes of pretreatment with substances known to modify the response to mercurial diuretics.

\section{MATERIALS AND METHODS}

These studies were carried out on 17 patients, 13 of whom were in congestive heart failure. The latter were maintained on a restricted daily sodium intake of 8 to 10 meq. The non-cardiac subjects were on a regular hospital diet. Thiomerin was the mercurial generally employed, since it has no xanthine component which might independently influence the excretion of mercury while its tubular action is similar to that of other mercurials (2). Injections of Mercuhydrin were included in some cases for comparison.

By varying the time of injection of the mercurial in five patients on a metabolic ward, measurements of the initial 18 to 24 hour urinary mercury excretion were obtained. The 24 hour collections of urine, which were analyzed for mercury, electrolyte and creatinine content, were continued for periods of $\mathbf{3 5}$ to 93 days. Stools were

1 Supported in part by grants from the National Heart Institute, U. S. Public Health Service, Campbell Pharmaceutical Co., and the Martha M. Hall Foundation.

2 Eli Lilly Research Fellow in Medicine. collected and pooled for three day periods before analysis. In addition, 32 studies of the early course of mercury excretion were performed in ten patients. Breakfast was withheld, but moderate hydration was achieved by permitting the patient to drink about $500 \mathrm{ml}$. of water. Complete collections were insured by instilling distilled water and air into the bladder via a retained soft rubber catheter. Following two or three control collection periods, the mercurial was injected via the desired route, and urine collected, generally at 30 minute intervals, for three to seven hours. Then, the catheter was removed and additional urine specimens obtained by spontaneous voiding.

Chemical analyses of urine or blood were performed by the following methods: sodium and potassium by means of a Perkin-Elmer 52A lithium internal standard flame photometer; chloride by a modification of Sendroy's iodometric method (3) ; total mercury by the dithizone method, as modified by Gettler and Lehman (4); creatinine by Peters' (5) modification of the Folin-Wu method.

\section{RESULTS}

A. Excretion of mercury. The results are illustrated in Figures 1 through 9 and Table I. From Figure 1, showing total urinary mercury excretion of 17 subjects, several facts are evident. 1) As a result of early, relatively rapid excretion of mercury, half of the total $(2 \mathrm{ml}$. = $80 \mathrm{mg}$. mercury) dose appears in the urine within $2 \frac{1}{2}$ to three hours. Another 20 to $40 \mathrm{mg}$. is excreted within 18 to 24 hours. 2) There is a definite retardation in mercury excretion during the first few hours after subcutaneous, as compared with intravenous, injection. Subsequently, the difference in total mercury excretion between the two routes of administration disappears. 3) Pretreatment with ammonium chloride does not influence the rate or completeness of excretion of subcutaneously or intravenously administered mercurials.

Despite the fairly complete urinary excretion of mercury within 20 to 24 hours, the output of 
TABLE I

Urinary and fecal mercury excretion during extended periods of mercurial administration

The degree of diuresis is indicated in terms of daily urinary sodium excretion.

\begin{tabular}{|c|c|c|c|c|c|c|c|c|}
\hline \multirow{2}{*}{ Patient } & \multirow{2}{*}{ Day } & \multirow{2}{*}{\multicolumn{2}{|c|}{ Mercurial }} & \multirow{2}{*}{$\mathrm{UV}_{\mathrm{Hg}}$} & \multirow{2}{*}{ Fecal $\mathrm{Hg}$} & \multirow{2}{*}{$\mathrm{UV}_{\mathrm{Na}}$} & \multicolumn{2}{|c|}{$\begin{array}{l}\text { Percentage recovery of } \\
\text { injected mercury }\end{array}$} \\
\hline & & & & & & & Urine & Feces \\
\hline \multirow[t]{7}{*}{$\begin{array}{l}\text { J. McM., } \\
\text { M., } 33 \\
\text { R. H. D., } \\
\text { C. H. F. }\end{array}$} & $\begin{array}{l}1 \\
2 \\
3 \\
4 \\
5 \\
6 \\
7\end{array}$ & Th 2 & i.v. & $\begin{array}{c}\text { (mg./day) } \\
61.0 \\
6.6 \\
0 \\
0 \\
0 \\
=\end{array}$ & $\begin{array}{c}\text { (mg./day) } \\
0.8 \\
.8 \\
.8 \\
.4 \\
.4 \\
.4 \\
0\end{array}$ & $\begin{array}{c}\text { (meq./day) } \\
239 . \\
126 \\
47.7 \\
31.6 \\
28.5 \\
28.0 \\
15.0\end{array}$ & 84.5 & 4.5 \\
\hline & $\begin{array}{l}10 \\
11 \\
12 \\
13 \\
14\end{array}$ & Th 2 & i.v. & $\begin{array}{l}37.8 \\
8.6 \\
0 \\
-\end{array}$ & $\begin{array}{l}0 \\
0 \\
0.8 \\
.8 \\
.8\end{array}$ & $\begin{array}{c}187 \\
33.5 \\
3.64 \\
1.83 \\
6.53\end{array}$ & 58.0 & 3.0 \\
\hline & $\begin{array}{l}22 \\
23\end{array}$ & Th 2 & s.c. & $\begin{array}{r}47.9 \\
0.2\end{array}$ & $\begin{array}{l}1.1 \\
1.1\end{array}$ & $\begin{array}{c}56.3 \\
8.80\end{array}$ & 60.1 & 2.8 \\
\hline & $\begin{array}{l}24 \\
25 \\
26 \\
27\end{array}$ & Th 2 & s.c. & $\begin{array}{l}57.8 \\
1.4 \\
0.4 \\
0\end{array}$ & $\begin{array}{l}1.1 \\
1.1 \\
1.1 \\
1.1\end{array}$ & $\begin{array}{c}83.1 \\
18.8 \\
2.88 \\
0.94\end{array}$ & 74.5 & 5.5 \\
\hline & $\begin{array}{l}28 \\
29^{*} \\
30^{*} \\
31^{*} \\
32^{*}\end{array}$ & Th 2 & i.v. & $\begin{array}{c}68.9 \\
1.7 \\
0.4 \\
0 \\
0\end{array}$ & $\begin{array}{l}1.2 \\
1.2 \\
1.2 \\
1.0 \\
1.0\end{array}$ & $\begin{array}{c}25.0 \\
7.28 \\
5.16 \\
2.92 \\
3.17\end{array}$ & 88.7 & 7.0 \\
\hline & $\begin{array}{l}33 \\
34 \\
35 \\
36 \\
37 \\
38 \\
39 \\
40 \\
41 \\
42 \\
43 \\
44 \\
45 \\
46 \\
47 \\
48\end{array}$ & Th 2 . & i.v. & $\begin{array}{l}62.2 \\
1.7 \\
= \\
= \\
= \\
= \\
= \\
= \\
=\end{array}$ & $\begin{array}{l}1.0 \\
1.8 \\
1.8 \\
1.8 \\
1.0 \\
1.0 \\
1.0 \\
= \\
= \\
= \\
= \\
=\end{array}$ & $\begin{array}{r}78.7 \\
0.66 \\
.56 \\
.90 \\
1.40 \\
1.09 \\
1.55 \\
2.24 \\
2.90 \\
4.60 \\
3.50 \\
3.38 \\
1.75 \\
3.71 \\
3.66 \\
7.08\end{array}$ & . & 11.8 \\
\hline & $\begin{array}{l}49 \\
50 \\
51\end{array}$ & $\begin{array}{l}\text { Th } 1 \\
\text { Th } 1 \\
\text { Th } 1\end{array}$ & $\begin{array}{l}\text { s.c. } \\
\text { s.c. } \\
\text { s.c. }\end{array}$ & $\begin{array}{l}38.4 \\
34.0 \\
20.4\end{array}$ & $\begin{array}{l}0.5 \\
0.5 \\
0.5\end{array}$ & $\begin{array}{c}28.4 \\
18.5 \\
\text { Incomplete }\end{array}$ & 78.3 plus & 1.2 plus \\
\hline J. D., & $\begin{array}{r}1 \\
2 \\
3 \\
4 \\
5 \\
6 \\
7 \\
8 \\
9 \\
10 \\
11 \\
12 \\
13 \\
14\end{array}$ & $\begin{array}{l}\text { Th } 2 \\
\text { Th } 2 \\
\text { Th } 2 \\
\text { Th } 2 \dagger\end{array}$ & $\begin{array}{l}\text { s.c. } \\
\text { s.c. } \\
\text { s.c. } \\
\text { s.c. }\end{array}$ & $\begin{array}{r}0.9 \\
.8 \\
.4 \\
.4 \\
.1 \\
50.1 \\
56.2 \\
2.7 \\
71.0 \\
74.3 \\
3.4 \\
0.4 \\
.4 \\
.4\end{array}$ & $\begin{array}{l}0 \\
0 \\
0 \\
1.6 \\
1.6 \\
1.6 \\
2.1 \\
2.1 \\
2.1 \\
0.4\end{array}$ & $\begin{array}{c}10.8 \\
2.50 \\
6.31 \\
3.01 \\
1.47 \\
78.6 \\
138 . \\
52.5 \\
139 . \\
208 . \\
36.6 \\
19.2 \\
15.3 \\
17.8\end{array}$ & & \\
\hline
\end{tabular}


TABLE I-Continued

\begin{tabular}{|c|c|c|c|c|c|c|c|c|}
\hline \multirow{2}{*}{ Patient } & \multirow{2}{*}{ Day } & \multirow{2}{*}{\multicolumn{2}{|c|}{ Mercurial }} & \multirow{2}{*}{ UVHe } & \multirow{2}{*}{ Fecal $\mathrm{Hg}$} & \multirow{2}{*}{$\mathrm{UV}_{\mathrm{Na}}$} & \multicolumn{2}{|c|}{$\begin{array}{l}\text { Percentage recovery of } \\
\text { injected mercury }\end{array}$} \\
\hline & & & & & & & Urine & Feces \\
\hline & $\begin{array}{l}15 \\
16 \\
17 \\
18 \\
19\end{array}$ & & & $\begin{array}{l}\text { (mg./day) } \\
\quad .5 \\
0 \\
0 \\
0 \\
0.2\end{array}$ & $\begin{array}{c}\text { (ms./day) } \\
.4 \\
.4 \\
.2 \\
.2 \\
.2\end{array}$ & $\begin{array}{c}\text { (meg./day) } \\
14.6 \\
9.34 \\
8.16 \\
7.11 \\
5.45\end{array}$ & 81.2 & 4.0 \\
\hline & $\begin{array}{l}21 \\
22 \\
23 \\
24 \\
25 \\
26 \\
27 \\
28 \\
29 \\
30 \\
31 \\
32\end{array}$ & $\begin{array}{l}\text { Th } 2 \\
\text { Th } 2\end{array}$ & $\begin{array}{l}\text { i.v. } \\
\text { i.v. }\end{array}$ & $\begin{array}{c}78.5 \\
76.5 \\
4.7 \\
1.0 \\
0 \\
0 \\
0 \\
0 \\
0.3 \\
.2 \\
.2 \\
.1\end{array}$ & $\begin{array}{l}0.3 \\
.3 \\
.3 \\
1.5 \\
1.5 \\
1.5 \\
0 \\
0 \\
0 \\
= \\
=\end{array}$ & $\begin{array}{c}28.2 \\
33.8 \\
6.77 \\
2.76 \\
1.20 \\
0.90 \\
1.45 \\
1.04 \\
1.15 \\
1.39 \\
1.67 \\
1.05\end{array}$ & 100.8 & 3.4 \\
\hline & $\begin{array}{l}33 \\
34 \\
35 \\
36^{*} \\
37^{*} \\
38^{*}\end{array}$ & $\begin{array}{l}\text { Th } 2 \ddagger \\
\text { Th } 2 \ddagger\end{array}$ & $\begin{array}{l}\text { s.c. } \\
\text { s.c. }\end{array}$ & $\begin{array}{r}70.5 \\
60.4 \\
9.0 \\
0.8 \\
.2 \\
.5\end{array}$ & $\begin{array}{l}0 \\
0 \\
0 \\
1.0 \\
1.0 \\
1.0\end{array}$ & $\begin{array}{c}96.5 \\
97.4 \\
12.7 \\
1.76 \\
0.58 \\
.66\end{array}$ & 88.4 & 1.9 \\
\hline & $\begin{array}{l}39 \\
40 \\
41\end{array}$ & $\begin{array}{l}\text { Th } 2 \ddagger \\
\text { Th } 2 \ddagger\end{array}$ & $\begin{array}{l}\text { s.c. } \\
\text { s.c. }\end{array}$ & $\begin{array}{r}63.2 \\
12.2 \\
0.6\end{array}$ & $\begin{array}{r}0.7 \\
.7 \\
.7\end{array}$ & $\begin{array}{c}66.8 \\
55.6 \\
1.13\end{array}$ & 47.5 & 1.3 \\
\hline & $\begin{array}{l}42 \\
43 \\
44 \\
45 \\
46 \\
47\end{array}$ & MH $2 \ddagger$ & s.c. & $\begin{array}{r}31.2 \\
21.1 \\
1.5 \\
0.1 \\
0 \\
0\end{array}$ & $\begin{array}{l}1.0 \\
1.0 \\
1.0 \\
= \\
=\end{array}$ & $\begin{array}{l}0.60 \\
2.83 \\
1.83 \\
0.46 \\
0.93 \\
0.38\end{array}$ & 67.4 & 3.7 \\
\hline $\begin{array}{l}\text { B. L., } \\
\text { M., } 57 \\
\text { R. H. D. }\end{array}$ & $\begin{array}{l}1 \\
2 \\
3 \\
4 \\
5\end{array}$ & Th 2 & s.c. & $\begin{array}{c}45.1 \\
3.6 \\
0\end{array}$ & $\begin{array}{r}0.4 \\
.4 \\
.4 \\
1.8 \\
1.8\end{array}$ & $\begin{array}{c}2.06 \\
2.51 \\
40.5 \\
5.90 \\
1.75\end{array}$ & 60.9 & 6.0 \\
\hline $\begin{array}{c}\text { C. H. F. } \\
\begin{array}{c}\text { Renal } \\
\text { disease }\end{array}\end{array}$ & $\begin{array}{r}6 \\
7 \\
8 \\
9 \\
10 \\
11 \\
12 \\
13 \\
14\end{array}$ & Th 2 & s.c. & $\begin{array}{l}45.3 \\
4.4 \\
0 \\
0 \\
0 \\
0 \\
0 \\
0 \\
0\end{array}$ & $\begin{array}{r}1.8 \\
1.8 \\
1.8 \\
1.8 \\
0.9 \\
.9 \\
.9 \\
0.3 \\
.3\end{array}$ & $\begin{array}{c}40.5 \\
18.1 \\
1.23 \\
1.05 \\
1.36 \\
1.46 \\
1.57 \\
1.29 \\
1.29\end{array}$ & 62.2 & 13.1 \\
\hline & $\begin{array}{l}15 \\
16 \\
17 \\
18 \\
19 \\
20 \\
21\end{array}$ & $\begin{array}{l}\text { Th } 2 \ddagger \\
\text { Th } 2 \\
\text { Th } 2 \ddagger\end{array}$ & $\begin{array}{l}\text { s.c. } \\
\text { s.c. } \\
\text { s.c. }\end{array}$ & $\begin{array}{r}27.5 \\
37.7 \\
8.4 \\
43.1 \\
8.0 \\
1.9 \\
\text { Tr. }\end{array}$ & $\begin{array}{l}.3 \\
5.5 \\
5.5 \\
5.5 \\
2.4 \\
2.4 \\
2.4\end{array}$ & $\begin{array}{r}38.0 \\
29.4 \\
1.46 \\
2.41 \\
0.86 \\
.88 \\
.96\end{array}$ & 52.8 & 10.0 \\
\hline & $\begin{array}{l}22 \\
23 \\
24 \\
25\end{array}$ & $\begin{array}{l}\text { Th } 2 \ddagger \\
\text { Th } 2 \ddagger\end{array}$ & $\begin{array}{l}\text { s.c. } \\
\text { i.m. }\end{array}$ & $\begin{array}{r}33.7 \\
37.9 \\
10.0 \\
2.8\end{array}$ & $\begin{array}{r}0.8 \\
.8 \\
.8 \\
11.0\end{array}$ & $\begin{array}{c}48.5 \\
160 . \\
29.0 \\
0.92\end{array}$ & & \\
\hline
\end{tabular}


TABLE I-Continued

\begin{tabular}{|c|c|c|c|c|c|c|c|c|}
\hline \multirow{2}{*}{ Patient } & \multirow{2}{*}{ Day } & \multicolumn{2}{|c|}{ Mercurial } & \multirow{2}{*}{ UVEE } & \multirow{2}{*}{ Fecal $\mathrm{Hg}$} & \multirow{2}{*}{ UVNa } & \multicolumn{2}{|c|}{$\begin{array}{l}\text { Percentage recovery of } \\
\text { injected mercury }\end{array}$} \\
\hline & & & & & & & Urine & Feces \\
\hline & $\begin{array}{l}26 \\
27 \\
28 \\
29\end{array}$ & $\begin{array}{l}\text { Th } 2 \\
\text { Th } 2\end{array}$ & $\begin{array}{l}\text { s.c. } \\
\text { s.c. }\end{array}$ & $\begin{array}{c}\text { (ms./day) } \\
37.8 \\
51.5 \\
8.3 \\
1.5\end{array}$ & $\begin{array}{c}\text { (ms./day) } \\
11.0 \\
11.0 \\
1.4 \\
1.4\end{array}$ & $\begin{array}{c}\text { (meq./day) } \\
35.2 \\
11.1 \\
20.7 \\
0.62\end{array}$ & 57.4 & 11.9 \\
\hline & $\begin{array}{l}\mathbf{3 0} \\
\mathbf{3 1} \\
\mathbf{3 2} \\
\mathbf{3 3} \\
\mathbf{3 4} \\
\mathbf{3 5} \\
\mathbf{3 6}\end{array}$ & $\begin{array}{r}\text { Th } 2 \\
\text { MH } 2\end{array}$ & $\begin{array}{l}\text { s.c. } \\
\text { i.m. }\end{array}$ & $\begin{array}{r}45.3 \\
46.5 \\
9.6 \\
2.6 \\
1.5 \\
0.9 \\
\text { Tr. }\end{array}$ & $\begin{array}{l}1.4 \\
1.0 \\
1.0 \\
1.0 \\
1.0 \\
1.0 \\
1.0\end{array}$ & $\begin{array}{r}6.99 \\
1.19 \\
0.96 \\
.86 \\
1.15 \\
0.94 \\
1.03\end{array}$ & 66.5 & 4.6 \\
\hline & $\begin{array}{l}37 \\
38 \\
39 \\
40 \\
41 \\
42\end{array}$ & $\begin{array}{l}\text { Th } 2 \\
\text { Th } 2 \\
\text { Th } 2\end{array}$ & $\begin{array}{l}\text { s.c. } \\
\text { i.v. } \\
\text { i.m. }\end{array}$ & $\begin{array}{r}37.7 \\
50.3 \\
11.6 \\
43.6 \\
10.8 \\
2.7\end{array}$ & $\begin{array}{l}2.3 \\
2.3 \\
2.3 \\
5.4 \\
5.4 \\
5.4\end{array}$ & $\begin{array}{l}1.31 \\
8.00 \\
2.27 \\
5.49 \\
2.14 \\
0.59\end{array}$ & 65.3 & 9.6 \\
\hline
\end{tabular}

* Ammonium chloride.

† Monotheamin $0.5 \mathrm{gm}$., i.v. with mercurial.

$\ddagger$ Aminophylline $0.5 \mathrm{gm}$., i.v. with mercurial.

mercury, as shown in Figures 2, 3, and 4 and Table I, continues. Thus, measurable amounts were found in the urine for three days, and in the feces, during several subsequent three-day collection periods. However, the amount in the feces only rarely exceeded 1 to $2 \mathrm{mg}$. per day, except in

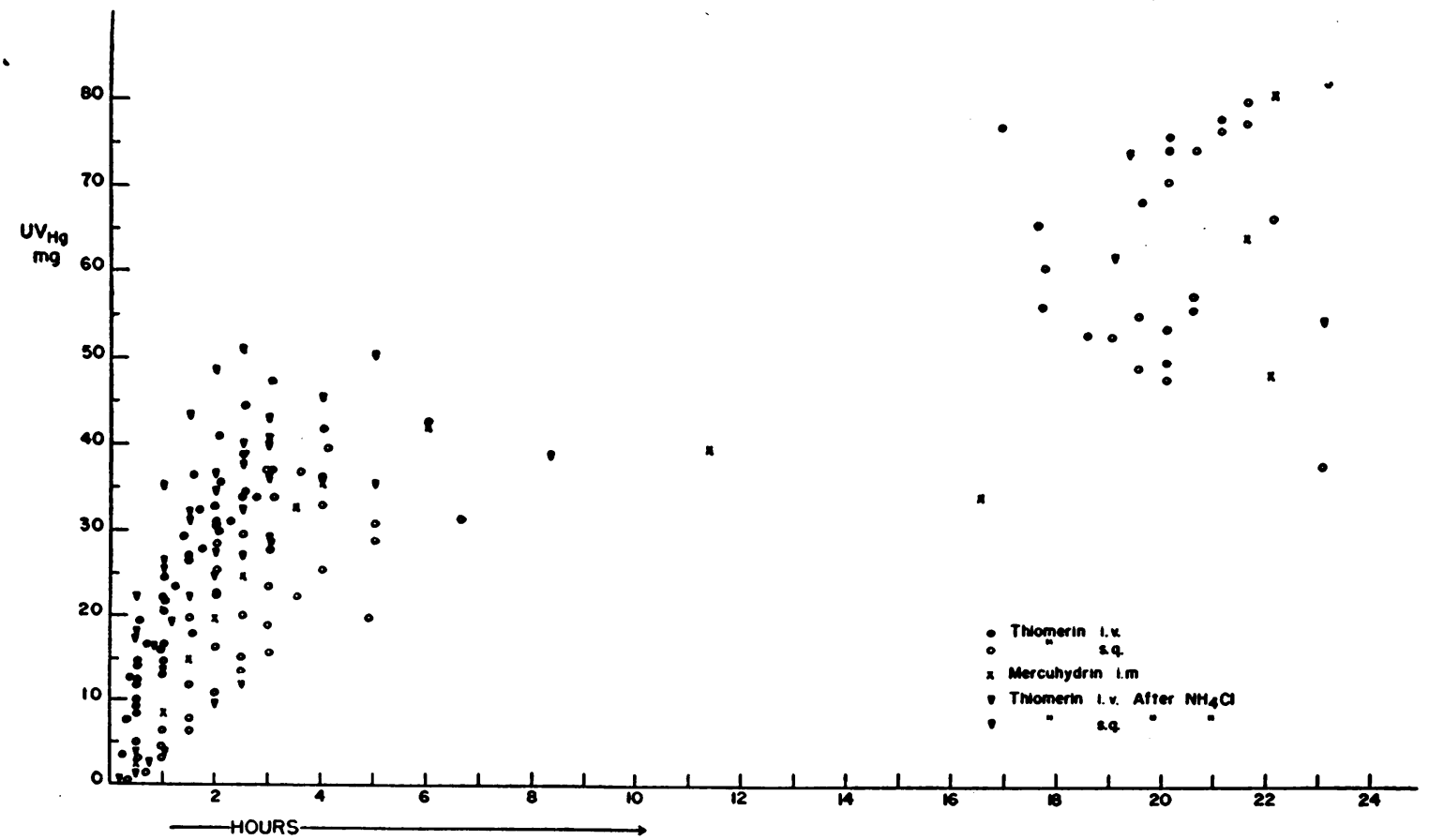

Fig. 1. Cumulative Urinary Mercury Excretion in Patients Receiving 2 ml. (80 Mg.) of a Mercurial Diuretic 


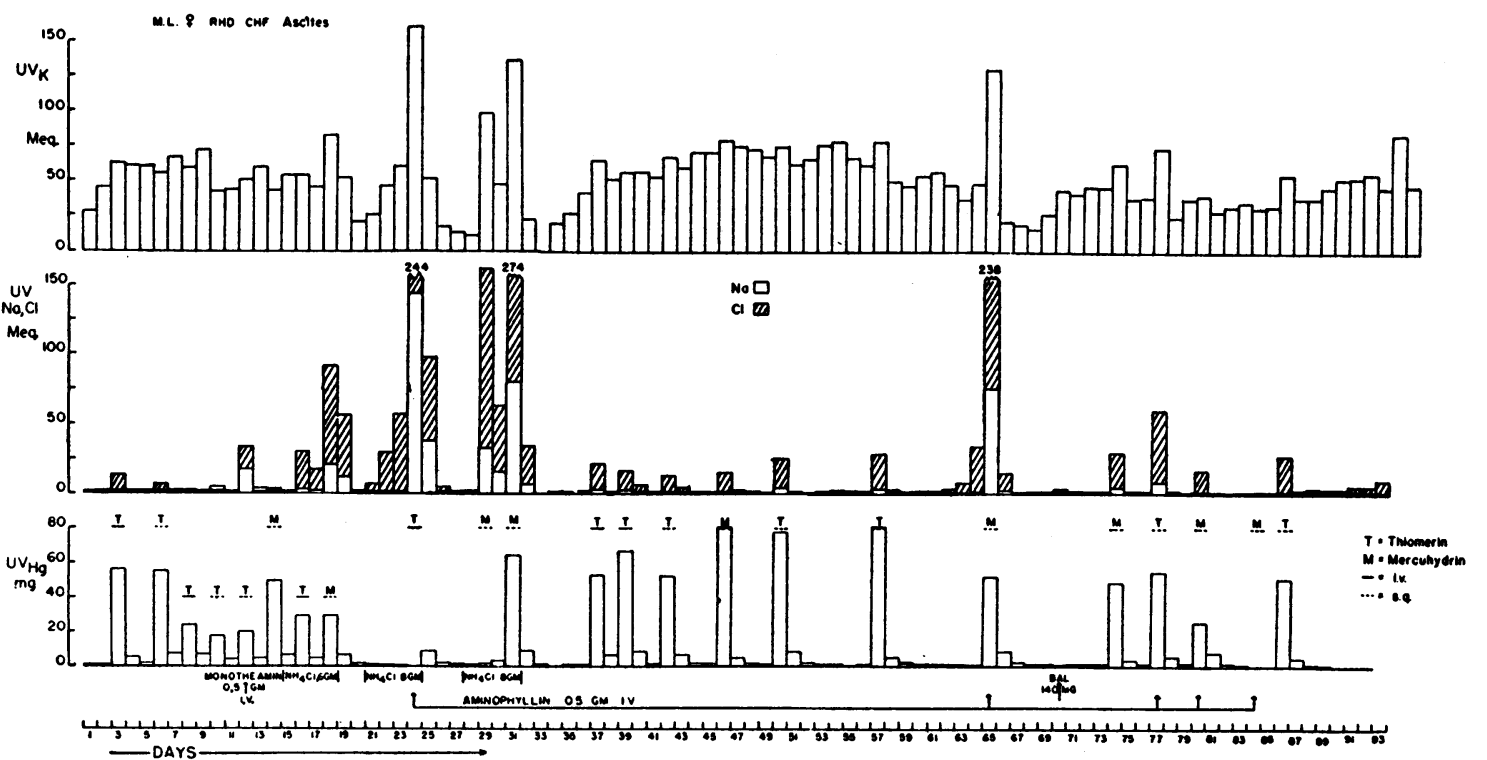

Fig. 2. Daily Urinary Excretion of Electrolytes and Mercury Following the Administration of Mercurials In Figures 2, 3 and 4, the dose of mercury is represented by lines above the rectangles depicting mercury excretion. Note that BAL failed to produce any increased excretion of mercury.

one patient (B. L.) with renal insufficiency, whose urinary output of mercury was considerably reduced.
B. Relation between mercury excretion and diuresis. In Figures 2, 3, and 4 and Table I are shown also the degree of diuresis as meas-

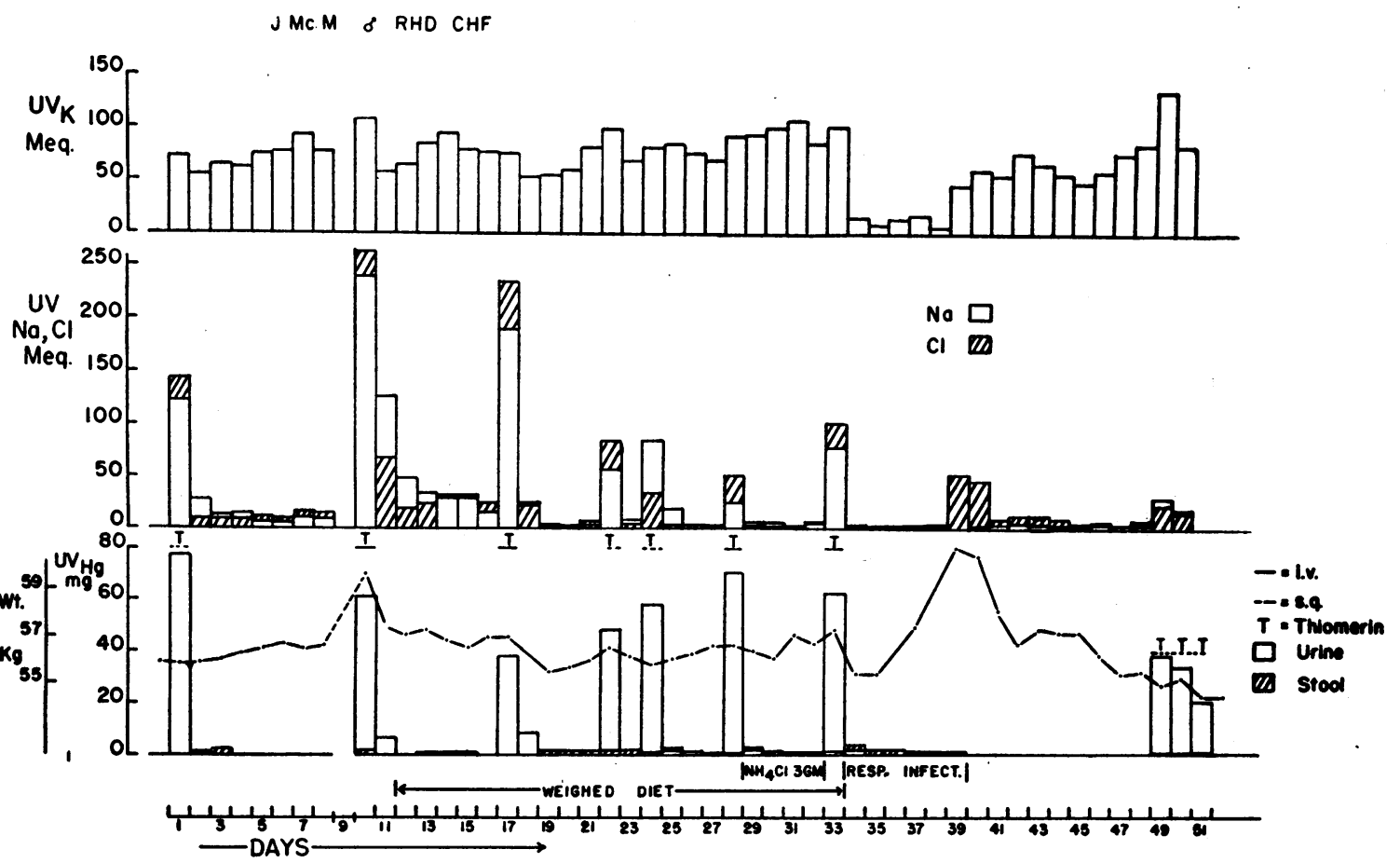

Fig. 3. Daily Urinary and Fecal Excretion of Mercury and Urinary Electrolyte Excretion Following the Administration of Mercurials 
ured by daily electrolyte excretion (sodium, potassium, chloride) and weight loss, and urinary and fecal (Figure 3) mercury excretion after repeated administration of mercurials. The lack of a simple relationship between the magnitude of diuretic response and mercury output is apparent in every patient. This independence of mercury excretion from diuresis was encountered not only in the longer (24 hour) excretion studies, but in the shorter experiments as well. Despite wide fluctuations in diuresis, both random and as a result of pre-treatment, urinary mercury excretion tended to remain fairly constant (Figures 5 and 6).

C. Influence of pre-treatment with ammonium chloride and desoxycorticosterone acetate on mercury excretion. The influence of pre-treatment with ammonium chloride on the early urinary excretion of mercury in individual patients is shown in Figures 5, 6, and 8. Following the first injec- tion of Thiomerin, Patient J. McM. (Figure 5) in moderately severe congestive heart failure was given ammonium chloride, $9 \mathrm{gm}$. daily for three days, prior to receiving the second injection. The ascending, broken line curves represent total urinary mercury excretion. In such cumulative curves, any analytical errors must affect every subsequent point, thereby tending to perpetuate early dissimilarities. Therefore, the average rate of mercury excretion (mg./min.) during each period, the differential of the previous curve, is also plotted. The resulting descending, single, solid line curve, fitting both sets of points, demonstrates a striking similarity in the rate, which indicates that ammonium chloride does not affect urinary mercury output. Other examples are seen in Figures 6 and 8. Similarly, no effect on fecal excretion of mercury was noted (Figures 3 and 4, Table I).
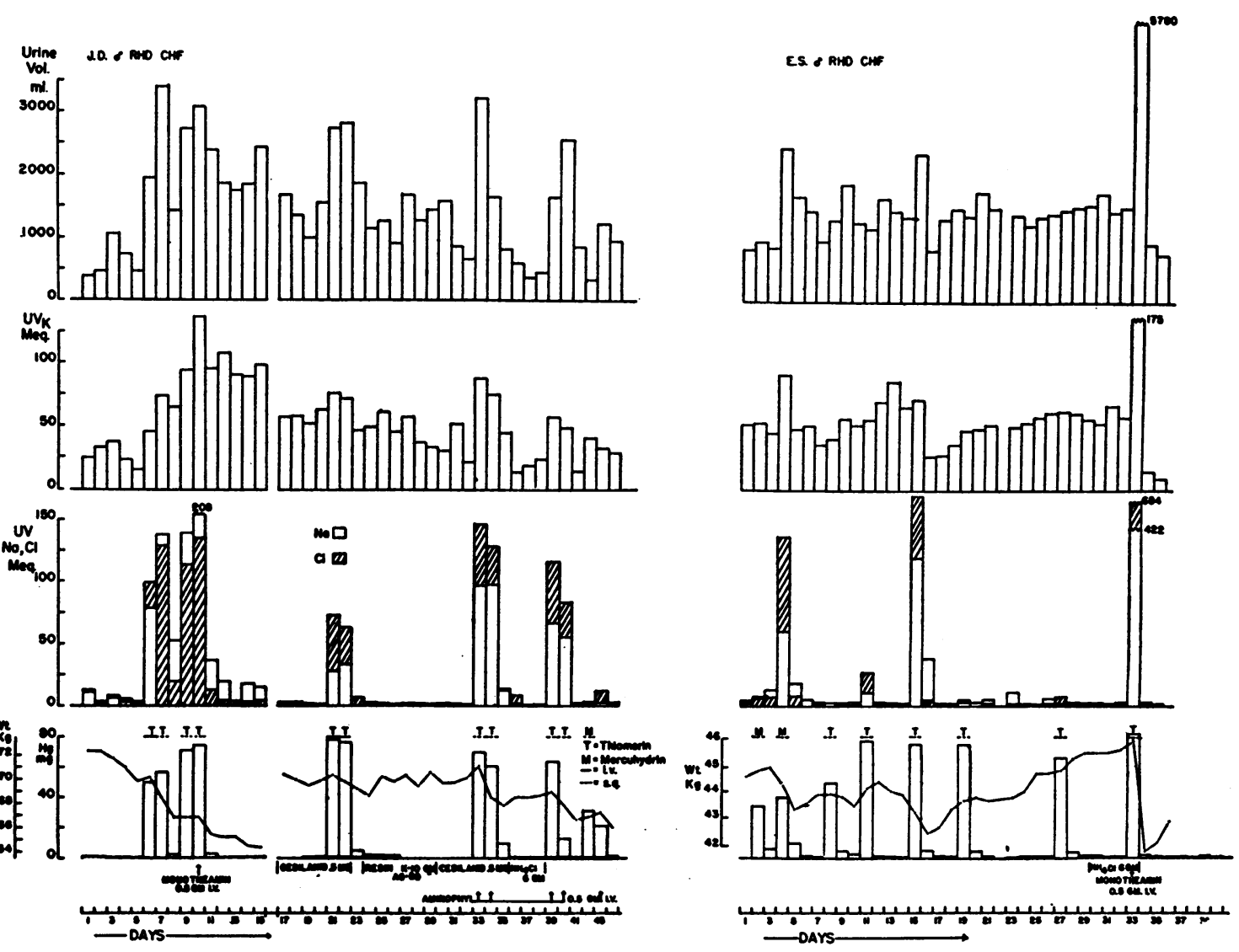

Fig. 4. Daily Urinary and Fecal Excretion of Mercury and Urinary Electrolyte Excretion Following the Administration of Mercurials 
The effect of desoxycorticosterone acetate ${ }^{8}$ on the urinary excretions of mercury following intravenous administration of Thiomerin to a patient (G. R.) prior to and after three daily doses of $20 \mathrm{mg}$. of DCA is also shown in Figure 6.

3 We are grateful to the Schering Corp. for making a supply of Cortate available to us.
As expected, the DCA inhibited the degree of mercurial diuresis, presumably by increasing the renal tubular reabsorption of sodium, chloride and water (upper curves). Nevertheless, the excretion of mercury following DCA administration was the same as that occurring prior to or after ammonium chloride. Thus, neither the

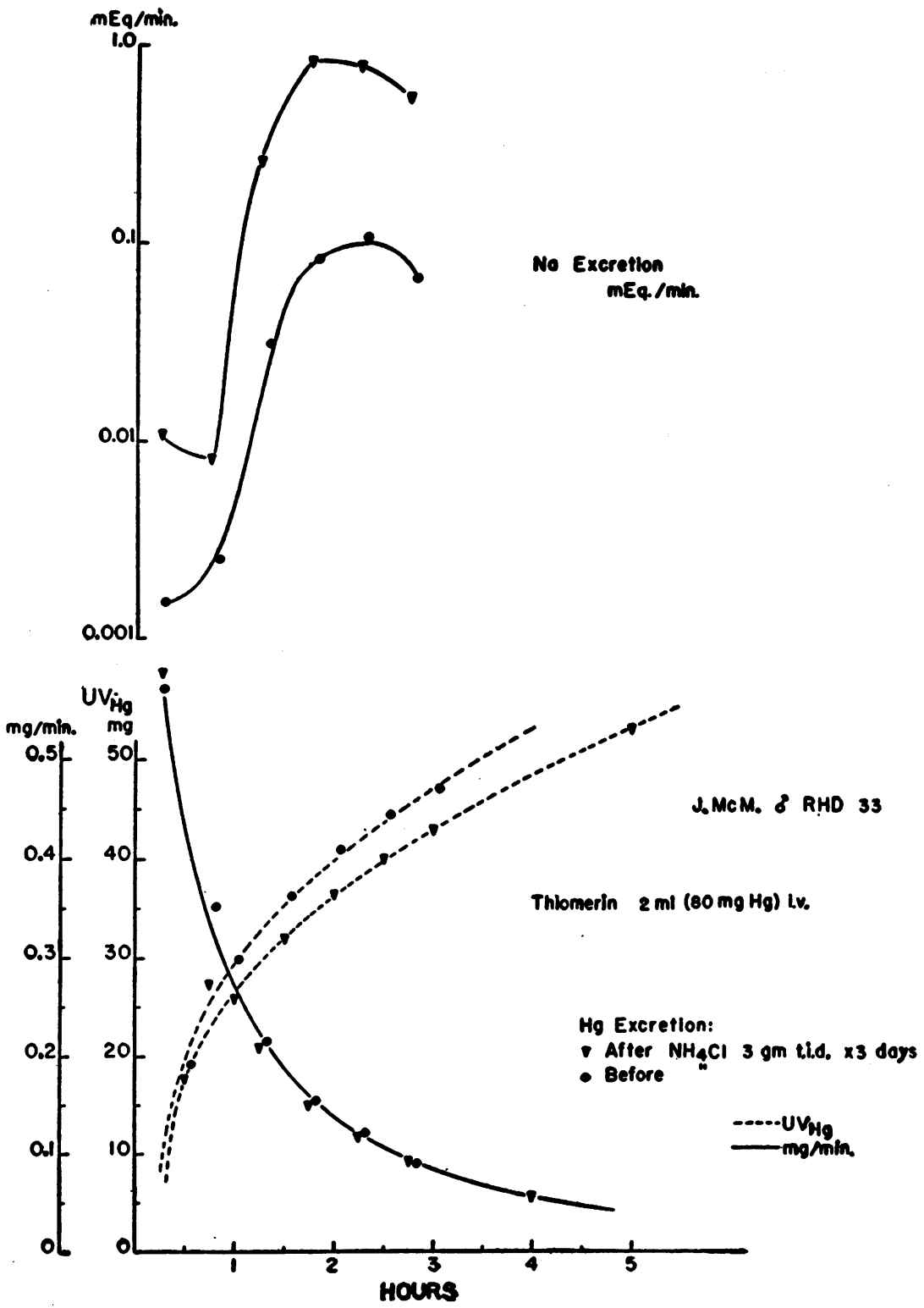

Fig. 5. A Comparison of Urinary MERcury and Sodrum Excretion after a Mercurtal Diuretic with and without Pee-Treatacknt with Ammonium Chloride

The broken lines represent cumulative total excretion, and the solid line, rate of excretion of mercury. 
increase nor inhibition of mercurial diuresis by line (Figure 9). In Patient A. O., to whom 0.5 the agents employed affected significantly the rate of excretion of mercury.

D. Effect of aminophylline on mercury excretion. gm. of aminophylline was given into a separate vein simultaneously with the intravenous adminisThe rate of excretion of mercury may, however, be increased by the administration of aminophyltration of Thiomerin, the excretion of mercury was markedly increased during the first $30 \mathrm{~min}$ utes. However, following and presumably as a
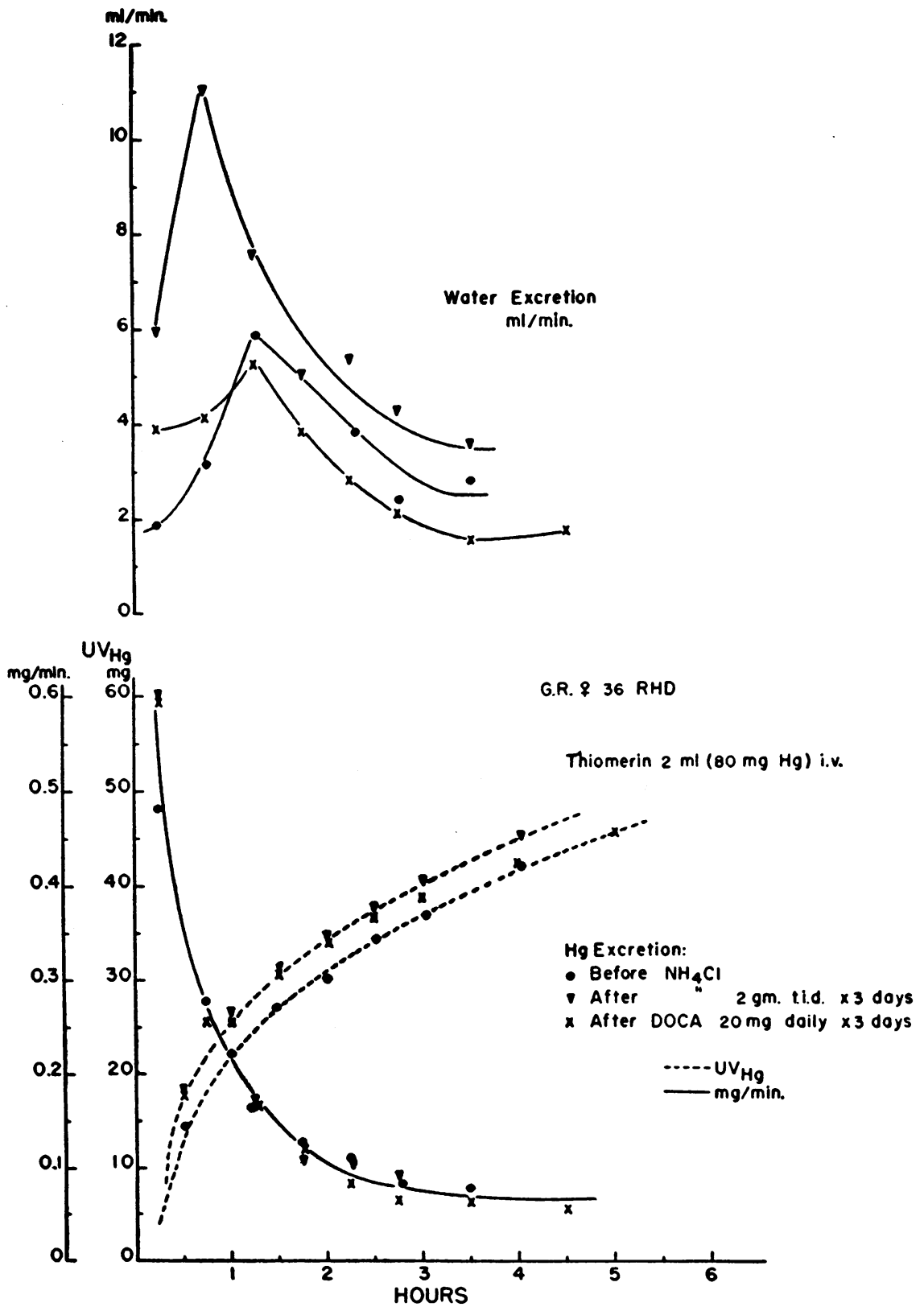

Fig. 6. A Comparison of Urinary Water and Mercury Excretion After a Mercurial Diuretic with and without Ammonium Chloride and Following DCA AdMinistration

The broken and solid lines have the same significance as in Figure 5. 


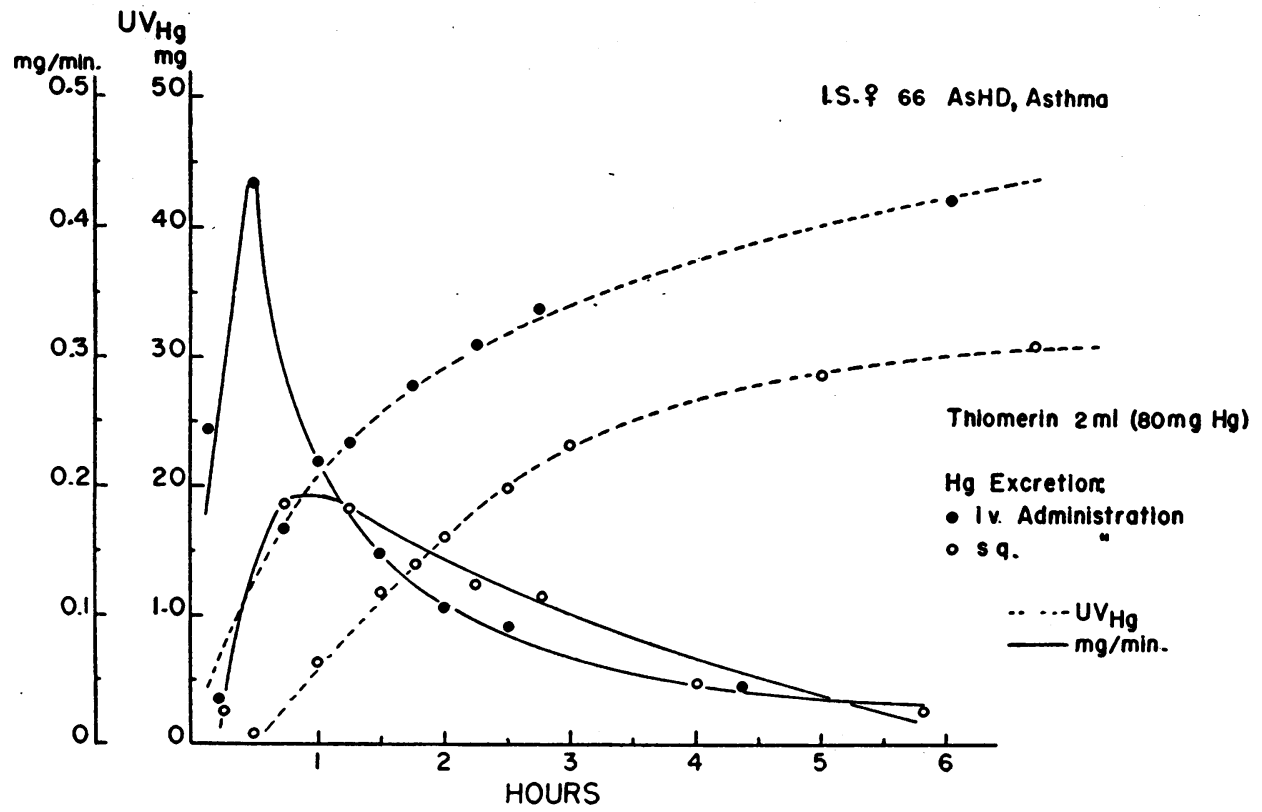

Fig. 7. A Comparison of Urinary Mercury Excretion Following Intravenous and Subcutaneous Administration

Note that after the initial lag, the rate of excretion of mercury after absorption from the subcutaneous site may exceed that after intravenous injection, probably because at this time, there is more mercury available for excretion in the former case.

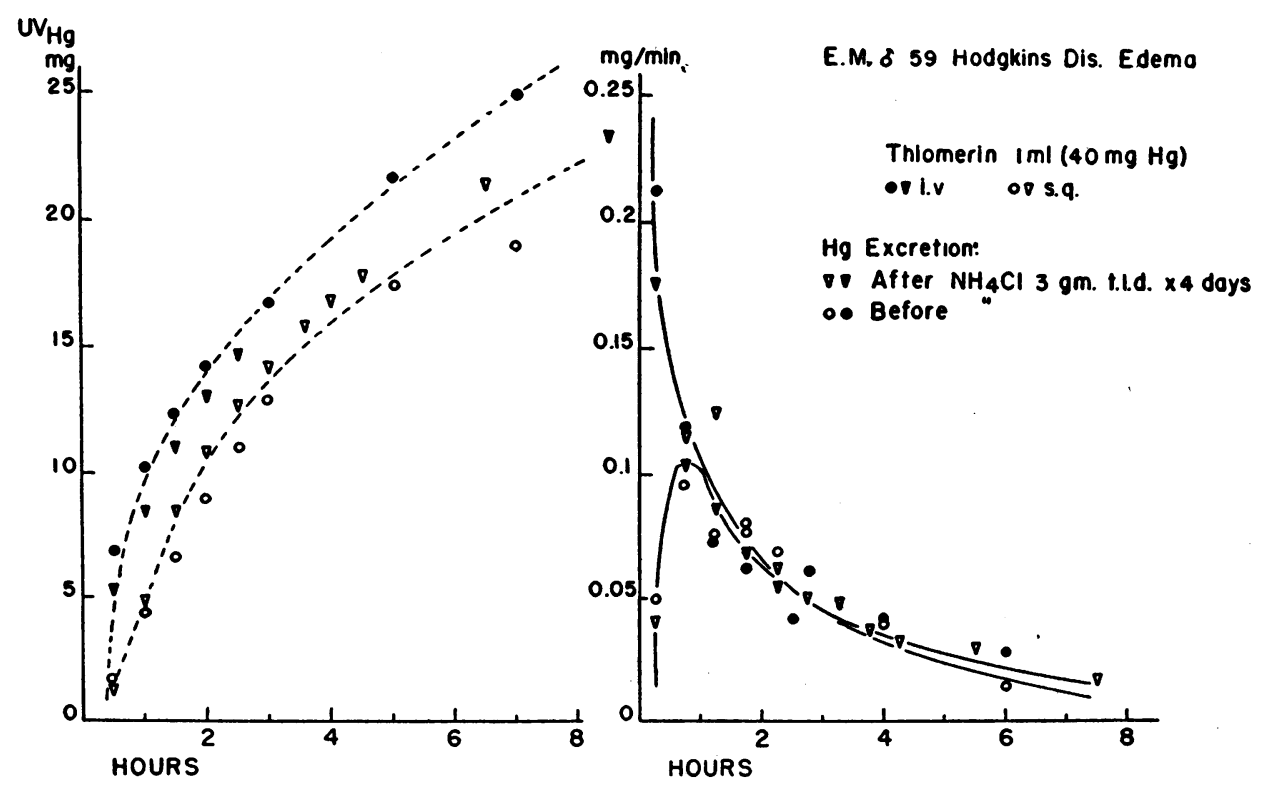

Fig. 8. Urinary Excretion in the Same Subject on Four Separate Trials

Note both the initially retarded rate of excretion after subcutaneous administration and the lack of effect of ammonium chloride. 
URINARY AND FECAL EXCRETION OF MERCURY

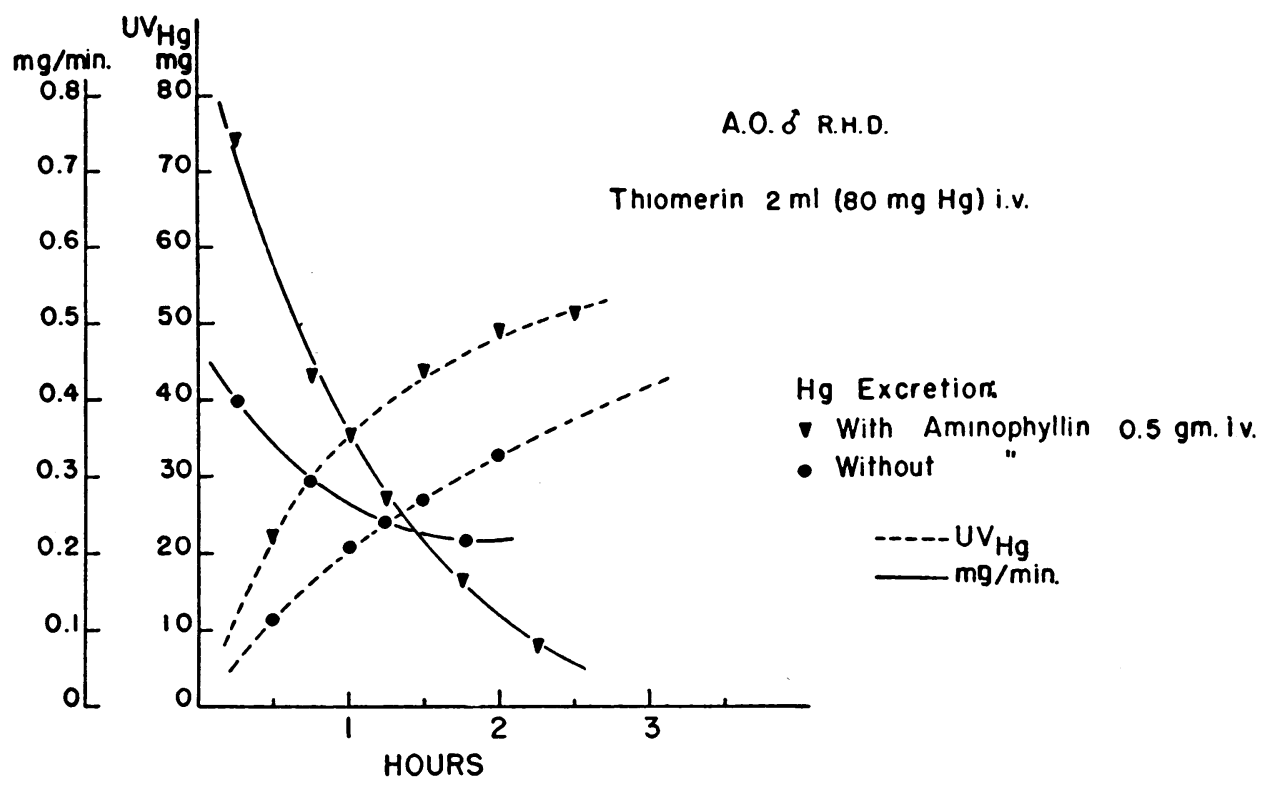

Fig. 9. The Effect of Simultaneous Intravenous Injection of Thiomerin and AminoPHYLLINE ON THE EXCRETION OF MERCURY IN THE URINE

Note that the early increased rate of excretion is followed by a rapid decline in the rate of mercury excretion.

result of, the rapid initial loss of mercury, the rate of excretion fell sharply, and after one and a half hours was slower than when the mercurial was given alone.

E. Effect of route of administration on mercury excretion. In previous studies from this laboratory (2), there was demonstrated a delay in the diuretic response to Thiomerin on subcutaneous, as compared with intravenous administration. This lag was attributed to the time required for absorption of the drug. This conclusion is strengthened by the results shown in Figures 7 and 8 in which the rates of mercury excretion after administration via both routes are compared. The delay in excretion of mercury after subcutaneous injection results in a significant retardation of total mercury output during the early period. However, following this initial delay of 30 to 60 minutes, the average rate of mercury excretion during subsequent collection periods equalled that following intravenous injection. Thus in subject E. M. (Figure 8), following the interval required for local absorption of the mercurial, the rate of urinary mercury excretion on four separate occasions followed the same general course (unaltered by ammonium chloride pre-treatment).

\section{DISCUSSION}

The recovery of mercury in the urine following administration of Thiomerin or Mercuhydrin in this series of patients is in agreement with results reported previously by one of us (6) and with those of Sollmann, Schreiber, and Cole (7) and Burch and associates (8). The last named investigators administered Mercuhydrin containing radiomercury and followed urinary excretion by physical methods. The analytical error (9) thus incurred is probably larger than in those studies using chemical methods in which the error is 3 to 5 per cent. However, the data described above corroborate those of Burch in several significant respects. Firstly, although the 24 hour excretion was fairly complete, generally some mercury was still present in the urine after this time. Secondly, the most rapid rate of mercury excretion occurred prior to the onset of diuresis. Thus, our estimation of $2 \frac{1}{2}$ to three hours for $U_{1 / 2}$, the time required for excretion of half the quantity of intravenously injected mercury (Figure 1), is similar to that of Burch and coworkers (8). Thirdly, the relative lag in mercury excretion on subcutaneous compared with 
intravenous injection in our smaller series is in accord with their results on the intramuscular route of administration. Fourthly, one patient (B. L.) with pre-existing renal disease excreted relatively smaller amounts of mercury in the urine and larger amounts in the feces in comparison with the other patients studied.

Few data on fecal mercury excretion following administration of organic mercurials are available for comparison. Lomholt (10) reported that one-sixth to one-third of the total mercury excretion occurred via the gastrointestinal tract following long term treatment with mercury ointments. However, following the injection of mercurial diuretics, the fraction of excreted mercury appearing in the feces is much smaller. Furthermore, it will be seen from the last columns of Table I that the fecal and urinary excretion of mercury together are not sufficient to account for all the mercury administered. Kwit and associates (11) have recently proposed a regimen for the treatment of cardiac patients which requires daily administration of a mercurial diuretic and they state that all the mercury from a single injection is excreted in the urine within 24 hours. This is not confirmed by the results reported above nor by the literature cited $(6,8)$. Thus from Table $I$ it seems clear that significant amounts of mercury are excreted during the second 24 hour period and occasionally during the third 24 hour period and that an appreciable fraction of the administered mercury cannot be accounted for even though the urinary and fecal excretion are followed for an ample number of days after the injection. It must then be concluded that daily administration of $2 \mathrm{ml}$. of a mercurial diuretic would inevitably lead to accumulation of mercury in the body. It is difficult to assess the clinical significance of this observation at the present time. Butt and Simonsen (12) have shown that quite high concentrations of mercury can occur in the kidneys of patients treated with mercurial diuretics but were unable to correlate the magnitude of mercury storage with the occurrence of mercurial nephrosis.

A relative dissociation of the diuretic response from the rate of mercury excretion was consistently observed in patients without organic renal disease. This is not surprising, since, in the absence of marked changes in renal hemody- namics, the degree of diuresis may vary with the factors influencing the fluid and electrolyte distribution of the patient and the renal tubular reabsorption of electrolytes and water, whereas the mercury excretion tends to remain more constant from one injection to another.

The lack of effect of DCA on mercury excretion provides further evidence for the independence of mercury excretion from electrolyte or water diuresis. Although an inhibitory effect on diuresis is present, which is in part secondary to a renal tubular effect, mercury excretion is not significantly influenced by the increased reabsorption of electrolytes and water.

As mentioned above, even the markedly increased diuresis after ammonium chloride pretreatment is not accompanied by significant changes in the excretion of mercury. Therefore, ammonium chloride potentiation of mercurial diuresis probably does not depend upon increasing the quantity of mercury available to the kidneys, either by lengthening the time the mercury remains in the kidneys or by increasing the quantity of mercury brought to this organ. The former would tend to depress the rate of mercury excretion, the latter to enhance it. A combination of both of these factors could conceivably leave mercury excretion unchanged, but there is no evidence in support of this third alternative." At present, it can only be suggested that ammonium chloride augments mercurial diuresis by increasing the efficacy of that relatively small moiety of excreted mercury which causes inhibition of tubular reabsorption.

On the basis of existing data, little can be said concerning the relationship between renal excretion of mercury and the mechanism of the diuretic response. However, the early excretion of a large fraction of the injected mercury before the onset of diuresis supports the concept that relatively little of the administered mercurial is actively involved in the production of diuresis. It should be emphiasized that the method of mer-

It has been pointed out (13) that a state of acidosis, as produced by ammonium chloride, would favor the reabsorption of mercury from bone and other body stores, and thereby result in increased excretion. This was not observed during ammonium chloride pre-treatment (Figures 2 and 3, Table I), nor following one dose of BAL in Patient M. L. (Figure 2) who had previously had many injections of mercurials. 
cury analysis used in this investigation, like that for radiomercury, measures total mercury and does not distinguish between split-off or transformed mercury and that persisting as part of the original organic molecule. The fraction involved in diuresis has probably undergone chemical modification. The excretion of such modified mercury would perhaps be more directly related to the degree of diuresis but unfortunately, this relatively small quantity of mercury is masked by the simultaneous excretion of large quantities of unmetabolized drug. This may explain the failure to uncover any association between onset and extent of diuresis and total urinary excretion of mercury. Thus far, the estimation of different mercury fractions in the urine has not been feasible.

The effect of aminophylline may shed some light on the mechanism of mercury excretion. DeGraff, Batterman and Lehman (14) demonstrated that urinary excretion of mercury in rabbits was more rapid and complete when the intramuscularly injected mercurial was combined with theophylline. The present studies in one patient likewise indicate that theophylline (as aminophylline) accelerates urinary mercury excretion by independent pharmacologic action. It is quite possible that a similar mechanism obtained in the experiments of DeGraff and coworkers since theophylline is relatively loosely bound to the mercurial. The results here reported reveal also that the maximal effect of aminophylline occurs within the first half hour, during which time the rate of mercury excretion is almost doubled. Following this rapid removal and presumably secondary to it, the excretion of mercury falls sharply so as to cause an intersection of the two curves of Figure 9 at about one and one half hours. The rate of mercury excretion is thereafter greater following the control injection.

Although a separate tubular action producing diminished electrolyte reabsorption has been attributed to aminophylline, there is no reason to believe that mercury excretion would thereby be accelerated. In view of the initial increase in glomerular filtration produced by aminophylline (15), the simultaneous rapid rate of mercury excretion may be attributed to increased filtration of mercury at a time when the plasma concentration is high. Whether mercury is excreted by a filtration and resorption mechanism is not es- tablished as yet. Tubular excretion of mercury would tend to be reflected by renal mercury clearances in excess of the glomerular filtration rate, and perhaps by progressively higher clearances as the plasma concentration of mercury falls. That this is not the case is evident from the results of Burch and associates (8) and ourselves (16) in which renal clearances of mercury were found to be below the glomerular filtration rate, and, if anything, to fall during the first two hours following mercurial administration. Studies from this laboratory (16) indicate that mercury may be taken up by the kidney parenchyma and later released. In this sense, tubular excretion may be said to occur, but this would not apply to the early, rapid mercury excretion which is further accelerated by aminophylline. The problem is further complicated by protein binding of mercury, which, at the plasma levels encountered, would theoretically be virtually complete (17). However, during the first minutes following an injection, the amount of filterable mercury would be a function of the relative rates of mixing in the plasma and combination with protein and perhaps other compounds. Adequate evaluation of the renal excretion of mercury would, among other things, require clearance determinations over a wide range of plasma concentrations, probably too great to achieve safely in human subjects. More knowledge of the forms of excretion of mercury and their filterability is essential.

\section{SUMMARY AND CONCLUSIONS}

1. Following intravenous or subcutaneous injection of $2 \mathrm{ml}$. of Thiomerin or intramuscular injection of $2 \mathrm{ml}$. of Mercuhydrin, about 60 to 95 per cent of the injected mercury is excreted in the urine during the first 24 hours. Mercury continues to appear in the urine for the next day or so in highly variable amounts. Daily fecal excretion of mercury rarely exceeds 1 to $2 \mathrm{mg}$. for the days immediately following the injection but measurable quantities (greater than $0.3 \mathrm{mg}$.) may be recovered for some time thereafter.

2. Approximately 50 per cent of the mercury is excreted in the urine within $2 \frac{1}{2}$ to three hours after intravenous injection of a mercurial diuretic. After subcutaneous injection the rate of mercury excretion during the first 30 to 60 minutes is reduced. 
3. In most cases it is impossible to recover all the administered mercury in the excreta even when analyses are continued over a considerable period. Thiomerin and Mercuhydrin do not appear to differ significantly with respect to the fraction of the injected mercury which can be accounted for.

4. Neither ammonium chloride which enhances, nor DCA which inhibits, the diuretic response to mercurials affects the renal excretion of mercury.

5. In one patient, aminophylline, administered simultaneously with a mercurial diuretic, but into a separate vein, produced an early marked increase in urinary mercury excretion.

6. The significance of these findings with respect to the accumulation of mercury in the body after repeated injections and to the mechanism of renal mercury excretion is discussed.

\section{ACKNOWLEDGMENTS}

The authors gratefully express their appreciation to Morris and Lila Wolfman, Madie Ross, and Lillian Pollack, chemists, for their technical assistance, and to Anne Goehring, nurse, and Honore Guerin, dietitian, on the metabolic ward.

\section{REFERENCES}

1. Gold, H., Kwit, N. T., Modell, W., Hanlon, L. W., Kramer, M., Greenberg, S., Otto, H. L., Cotlove, E. W., Benton, J. G., Pearlmutter, M., and Zahm, W., A system for the routine treatment of the failing heart. Am. J. Med., 1947, 3, 665.

2. Grossman, J., Weston, R. E., Edelman, I. S., and Leiter, L., Studies on Thiomerin-a subcutaneously administerable mercurial diuretic. Circulation, 1950, 1, 508.

3. Van Slyke, D. D., and Hiller, A., Application of Sendroy's iodometric chloride titration to proteincontaining fluids. J. Biol. Chem., 1947, 167, 107.

4. Gettler, A. O., and Lehman, R. A., A simplified procedure for the determination of mercury in urine. Am. J. Clin. Path., 1938, 8, 161.

5. Peters, J. H., The determination of creatinine and creatine in blood and urine with the photoelectric colorimeter. J. Biol. Chem., 1942, 146, 179.
6. Lehman, R. A., King, E. E., and Taube, H., The pharmacology of Thiomerin. J. Pharmacol. \& Exper. Therap., 1950, 99, 149.

7. Sollmann, T., Schreiber, N. E., and Cole, H. H., Comparative diuretic response to clinical injection of various mercurials. Arch. Int. Med., 1936, 58, 1067.

8. Burch, G., Ray, T., Threefoot, S., Kelly, F. J., and Svedberg, A., The urinary excretion and biologic decay periods of radiomercury labeling a mercurial diuretic in normal and diseased man. J. Clin. Invest., 1950, 29, 1131.

9. Kelly, F. J., Ray, C. T., Threefoot, S. A., and Burch, G. E., Influence of self-absorption, volatilization and deliquescence in counting radioelements. $\mathrm{J}$. Lab. \& Clin. Med., 1950, 35, 606.

10. Lomholt, S., Absorption and elimination of mercury in the different methods used in the treatment of syphilis. Brit. J. Dermat., 1920, 32, 353.

11. Kwit, N. T., Modell, W., Hanlon, L. W., Benton, J. G., Cotlove, E. W., Pearlmutter, M., Greenberg, S. M., Kramer, M. L., and Gold, H., The daily dose of the mercurial diuretic and the maintenance dose to control congestive failure. Federation Proc., 1948, 7, 236.

12. Butt, E. M., and Simonsen, D. G., Mercury and lead storage in human tissues; with special reference to thrombocytopenic purpura. Am. J. Clin. Path., 1950, 20, 716.

13. Young, A. G., Taylor, F. H. L., and Merritt, H. H., The distribution and excretion of mercury. Arch. Dermat. \& Syph., 1930, 21, 539.

14. DeGraff, A. C., Batterman, R. C., and Lehman, R. A., The influence of theophylline upon the absorption of mercupurin and salyrgan from the site of intramuscular injection. J. Pharmacol. \& Exper. Therap., 1938, 62, 26.

15. Weston, R. E., and Escher, D. J. W., An analysis of the unresponsiveness to mercurial diuretics observed in certain patients with severe chronic congestive failure. J. Clin. Invest., 1948, 27, 561.

16. Weston, R. E., Grossman, J., Lehman, R. A., Ullmann, T. D., Halperin, J. P., and Leiter, L., Renal extraction and excretion of mercury in man following intravenously administered organic mercurial diuretics. J. Clin. Invest., 1951, 30, 1221.

17. Milnor, P. J., Binding of the mercury of an organic mercurial diuretic by plasma proteins. Proc. Soc. Exper. Biol. \& Med., 1950, 75, 63. 